\title{
ANÁLISE DO EMPODERAMENTO SOCIAL DE JOVENS E ADULTOS ATRAVÉS DO ENSINO COM METODOLOGIAS PARTICIPATIVAS: O CASO DO CURSINHO POPULAR PRÉ VESTIBULAR COLMEIA
}

\author{
Josely Rimoli, Lana A. Faria*
}

\section{Resumo}

O presente projeto de estudo visa analisar a contribuição de Metodologias Participativas no processo de Empoderamento Social de jovens e adultos que frequentam o Cursinho Pré-Vestibular Popular Colmeia. A motivação de tal estudo vem das observações dos processos metodológicos participativos vivenciados e relatados pelos estudantes do cursinho, os quais apontam que além das aprovações nos vestibulares o cursinho colabora no Empoderamento Social. A hipótese é a de que o desenvolvimento de Metodologias Participativas possibilita aos estudantes a experiência de aperfeiçoar a fala e postura em público, a valorização da autoestima e autonomia para formulação de opiniões, além da conquista da qualidade do acesso a informações, ou seja, verificar a colaboração das Metodologias Ativas e lúdicas na construção de um processo que viabiliza o Empoderamento Social dos estudantes. Trata-se de uma pesquisa qualiquantitativa, de caráter social, embasada nos preceitos da Pesquisa Participante e na Metodologia Problematizadora Freireana.

\section{Palavras-chave:}

\section{Empoderamento Social, Metodologias Participativas, Cursinho Pré-Vestibular Popular.}

\section{Introdução}

Associar o processo de acesso à escrita, de certa forma, a genealogia do termo empoderamento ou empowerment, é possível, muito embora a utilização crescente do termo tenha se dado a partir dos movimentos emancipatórios relacionados ao exercício de cidadania nos Estados Unidos ${ }^{1}$ (Baquero, 2012). Contudo, se faz essencial ressaltar que o processo de empoderamento não se restringe somente ao domínio da escrita, o mesmo desencadeou outras diversas conquistas de empoderamento individual e coletivo, tal como o voto feminino. No âmbito educacional, Paulo Freire trouxe a perspectiva de empoderamento, individual e de classe social, o que segundo Silva, Pinheiro e Chagas $(2016$, p. 6) "tem por base o diálogo, despido de vaidades e hierarquias intelectuais, é a tônica dessa pedagogia progressista, humanizante e revolucionária". Assim, objetiva-se especificamente: a) Verificar a possibilidade de colaboração das Metodologias Participativas na construção do ambiente solidário e empático entre os estudantes e entre professores e estudantes; b) Pesquisar a possibilidade de apoio das Metodologias Participativas no trabalho de prevenção do estresse e ansiedade pré-vestibular.

\section{Resultados e Discussão}

Para o desenvolvimento deste trabalho os sujeitos escolhidos para o universo amostral caracterizam-se por estudantes, das turmas vespertinas e noturnas, do Cursinho Colmeia frequentadores(as) dos espaços de Metodologias Participativas, especificamente as iniciativas: Café Literário e Aulas Interdisciplinares, compondo uma amostra de 30 estudantes. É válido ressaltar que a pesquisadora é a própria e única entrevistadora. Em sua abordagem qualitativa propõe realizar o acompanhamento da capacidade de construção argumentativa não verbal dos estudantes, através de produções escritas e na colocação quantitativa a aplicação de questionário semi-estruturado. Dentre os indagações e resultados destaque-se que ao serem questionados quanto ao impacto das vivências do
Cursinho em sua vida: 26,6\% (8 entrevistados) a passagem pelo Cursinho Pré-Vestibular Popular Colmeia proporcionou uma nova perspectiva de ensino, através de um ambiente descontraído e humanizado questões que potencializam o entendimento da realidade e da consciência cidadã, também são vistos, o que vai além da aprendizagem de conteúdo para os vestibulares.

\section{Conclusão}

Ao final desta pesquisa, avalia-se que se cumpriu os objetivos propostos, uma vez que através das resoluções do questionário comprovou-se quantitativamente, por meio da perspectiva dos entrevistados, que as Metodologias Participativas - especificamente as utilizadas nos projeto Café Literário e Aulas Interdisciplinares-, colaboram na construção de um ambiente solidário e empático entre os estudantes e entre professores, ao passo que também são ferramentas pedagógicas para o estresse e ansiedade pré-vestibular. A investigação também constatou que há contribuição das Metodologias Participativas no processo de Empoderamento Social dos estudantes do Cursinho Colmeia, visto que através do acompanhamento dos exercícios argumentativos escritos, pela metodologia qualitativa, constatou-se avanços significativos nos critérios relacionados a coerência argumentativa e exemplificações dos estudantes, porém recorda-se que o domínio da escrita não é o único fator gerador de empoderamento, inclui-se as vivências familiares, as condições econômicas e socioculturais.

\footnotetext{
BAQUERO, Rute Vivian Ângelo. Empoderamento: instrumento de emancipação social? Uma discussão conceitual. Revista Debates, Porto Alegre, v. 6 , n. 1, p. 173-187, jan-abr. 2012

SILVA, L. V. L.; PINHEIRO, M. R. D.; CHAGAS, N. S. O empoderamento como processo de conscientização e os sujeitos da educação. In: $3^{\circ}$ Congresso Nacional de Educação, 2016, Natal (RS). Editora Realize, 2016.
} 